\title{
The Implementation of Project Based Learning to Improve Student Creativity and Learning Outcomes
}

\author{
Enjang Ali Nurdin ${ }^{1}$, Wahyudin ${ }^{2}$ \\ \{enjang_cs@upi.edu ${ }^{1}$,wahyudin_sanusi@upi.edu ${ }^{2}$ \} \\ Department of Computer Science Education, Indonesia University of Education, Bandung, \\ Indonesia $^{1,2}$
}

\begin{abstract}
This research applied Project Based Learning in the Information System on Education Management (SIMP) course to see its effect on the creativity and learning outcomes of the student. The method used in this research is One Group Pretest-Posttest Design. Meanwhile one of the outcomes of this research is the design of SIMP. The results showed that the implementation of Project Based Learning learning methods in the Information System on Education Management course significantly influenced the level of student creativity and learning outcomes proved by the differences between pretest and posttest mean reached value of 30,5 and also normalized gain reached 0,60 which is included in moderate category. Based on hypothesis test there is significant differences after student get the implementation of project based learning to improve creativity and learning outcomes which is proved by tcount value $(6,418)$ and Sig. Value $(0.000)$ is bigger than 0.05 .
\end{abstract}

Keywords: Information System on Education Management (SIMP), Project Based Learning, Learning by Design, One Group Pretest-Post Test.

\section{Introduction}

Project Based Learning (PjBL) is a learning method that uses projects/activities as a medium. Learners explore, evaluate, interpret, synthesize, and information to produce various forms of learning outcomes. Project based learning has the following advantages that makes it stand out among other pedagogies; it engages learners, boosts cooperative learning skills, improves academic performance, develops high order thinking skills and builds positive relationships between students and teachers [1].

Project based learning technique has been successfully used in developed countries to improve students' achievement and also to prepare them for life outside classroom. In Britain, there has been marked improvement in test mean scores in science subjects as a result of implementation of project based learning pedagogy in teaching. In the United States of America, project based learning is well established through the support of the Buck Institute for Education (B.I.E) as a response to school reform efforts that required to equip learners with skill suitable in the knowledge based economy. In Japan and India, project based learning is also well established[2].

Learning creativity is often regarded as a skill based on natural talent, where only those who are talented can be creative. This assumption is not entirely true, although in reality it 
seems that certain people have the ability to create new ideas quickly and diverse. In fact the ability to think creatively is basically possessed by everyone.

Creativity and problem-solving skills are also the capabilities demanded by today's world of work. According to [3], some of the individual characteristics of the desired workforce are: (1) self-confidence, (2) motivation for achievement, (3) master basic skills such as reading, writing, listening, speaking, and computer literacy, (4) mastering thinking skills, such as problem solving, problem posing, decision making, analthical thinking, and creative thinking (4) creative thinking), and (5) master interpersonal skills, such as the ability to work in teams and negotiate.

Measurement of creative thinking skills is done by using creativity tests. The creative thinking test can be verbal, if the task demanded, expressed in words, or figural, if the task demanded is expressed in the form of a picture [4]. There are four characteristics of creative thinking according to [5], as a process involving elements of originality, fluency, flexibility and elaboration.

\section{Research Method}

This research is a development activity as well as an application carried out in collaboration with students and lecturers. Lecturers and students are a team who will design game applications based on experience, expertise, potential and existing conditions. From the design activities, it is expected that an SIMP idea or concept will be born that can provide cognitive and affective influence (in the form of student creativity). Furthermore, the SIMP will be tested in learning activities at class. This trial activity will always be accompanied by an evaluation and reflection process as an effort to improve SIMP.

In general, research and development activities will be carried out in three stages, that are 1) identification, analysis, development of the SIMP, 2) the SIMP trial phase, and 3) the evaluation and refinement of the SIMP. These three stages are inseparable part of an information system development cycle. In carrying out this research, the steps to be taken are as follows:

1. Research Preparation In this stage researcher determine the strategy of research

2. Data Collection (Application Requierements) and Design Analysis

At this stage, a learning strategy will be determined which will be integrated with the Project Based Learning method while determining the Type of Education Information that must be included in the SIMP. This is where students can design software and determine the technical components that needed to build the SIMP.

3. Implementation of Project Based Learning Learning

Researcher will be applied the Project Based Learning strategy to the students. By using quasi-experimental research methods (Quasi experiment). This mean that the experiment is an activity to examine an event or symptom that appears in certain conditions.

The method that used is Quasi Experiment with one group pretest and posttest design [6]. In a chart, the design of a single group pretest and posttest design can be described on Figure 1. 


\begin{tabular}{|lll|} 
Pretest & treatment & Posttest \\
\hline $\mathrm{O}_{1} \longrightarrow \mathrm{X}$ & $\longrightarrow \mathrm{O}_{2}$ \\
\hline
\end{tabular}

Fig. 1. One Group Pretest-Posttest Design.

O1 = Pre Test Value (Before Treatment)

$\mathrm{O} 2=$ Post Test Value (After Treatment)

$\mathrm{X}=$ Treatment (Group Counseling)

\section{Results and Discussion}

In pretest data analysis before the student given treatment in learning, students are given first pre-test to measure student initial ability. After that the student will be given treatment in terms of learning and after that given post-test to determine the increase student understanding. The result of pretest and posttest can be seen in Table 1.

Table 1. Pretest Descriptive Analysis.

\begin{tabular}{cccccc}
\hline & $\mathrm{N}$ & Minimum & Maximum & Mean & $\begin{array}{c}\text { Std. } \\
\text { Deviation }\end{array}$ \\
\hline Pre_Test & 30 & 5 & 75 & 49,17 & 20,090 \\
Valid N(listwise) & 30 & & & & \\
\hline
\end{tabular}

From 30 students, their mean in pretest reached 49.17. The highest pretest score reached a value of 75 while the lowest score reaches a value of 5 . Post-test is done to determine student understanding and skill improvement. After the post-test data results obtained, the next step is to perform data processing to obtain descriptive statistics of the data as shown in Table 2 .

Table 2. Posttest Descriptive Analysis.

\begin{tabular}{cccccc}
\hline & N & Minimum & Maximum & Mean & $\begin{array}{c}\text { Std. } \\
\text { Deviation }\end{array}$ \\
\hline Post_Test & 30 & 35 & 100 & 79,67 & 16,554 \\
\hline Valid N (listwise) & 30 & & & & \\
\hline
\end{tabular}

From 30 students, their mean in posttest reached 79.67. The highest posttest score reached a value of 100 while the lowest score reaches a value of 35 . The next step is using normalized gain to determine effect of the implemention of Project Based Learning. The results of normalized gain can be seen in Table 3 . 
Table 3. Normalized Gain.

\begin{tabular}{cccccc}
\hline Test & $\mathbf{X}_{\text {ideal }}$ & $\overline{\boldsymbol{x}}$ & Gain & $\langle\boldsymbol{g}\rangle$ & Criteria \\
\hline Pretest & \multirow{2}{*}{100} & 49,17 & \multirow{2}{*}{30,5} & 0,60 & Moderate \\
Posttest & & 79,67 & & & \\
\hline
\end{tabular}

The difference (gain) between pre-test and post-test results is 30.5. From the calculation of the normalized gain obtained by the average value $<-g>-$ is 0.60 . After comparing the value of $\langle F \mathrm{~g}\rangle \downarrow$ obtained by the criterion value $\langle F \mathrm{~g}\rangle-$ it can be concluded that The Implementation of Project Based Learning in Information System on Education Management Course is classified as "moderate".

The last stage to see effect of The Implementation of Project Based Learning in Information System on Education Management Course is by using Independent Samples Test that can be seen in Table 4 .

Table 4. Independent Samples Test.

\begin{tabular}{llccccc}
\hline & & \multicolumn{2}{c}{$\begin{array}{c}\text { Levene's Test for } \\
\text { Equality of Variances }\end{array}$} & \multicolumn{2}{c}{ t-test for Equality of Means } \\
& F & Sig. & t & df & $\begin{array}{c}\text { Sig. (2- } \\
\text { tailed) }\end{array}$ \\
\hline \multirow{3}{*}{ Score } & $\begin{array}{l}\text { Equal variances } \\
\text { assumed } \\
\text { Equal variances not } \\
\text { assumed }\end{array}$ & 7,100 &, 003 & 6,418 & 58 &, 000 \\
& & & 6,418 & 55,954 &, 000 \\
\hline
\end{tabular}

There is significant differences after student get the implementation of project based learning to improve creativity and learning outcomes which is proved by $\mathrm{t}_{\text {count }}$ value $(6,418)$ and Sig. Value (0.000) is bigger than 0.05 .

\section{Conclusion}

The results showed that the implementation of Project Based Learning learning methods in the Information System on Education Management course significantly influenced the level of student creativity and learning outcomes proved by the differences between pretest and posttest mean reached value of 30,5 and also normalized gain reached 0,60 which is included in moderate category. Based on hypothesis test there is significant differences after student get the implementation of project based learning to improve creativity and learning outcomes which is proved by $\mathrm{t}_{\text {count }}$ value $(6,418)$ and Sig. Value $(0.000)$ is bigger than 0.05 .

\section{References}

[1] Thomas, H, W. Mergendoller, J. R. Michaleson, A.: Projects based learning: A handbook for middle and high school teachers. Navato, CA: the Buck institute for Education (2000) 
[2] Biggs and John.: Teaching for Quality learning at University (2ndEdn.). Berkshire: Open University press (2003)

[3] Career Center Maine Departmeny of Labor.: Today's Work Comepetence in Maine. http://mainegov-images.informe.org/labor/lmis/pdf/ EssentialWorkCompetencies.pdf (2004)

[4] Munandar, U.: Developing the Talents and Creativity of Students, Guidance for Teachers and Parents. Jakarta: PT. Gramedia Widiasarana Indonesia (2009)

[5] Torrance, E,. P.: The Torrance Tests of Creativity Thingking Norms-Tecknical Manual Figural (Streanlined) Forms A \& B. Benseville: Scolastic Testing Service, Inc (1990)

[6] Fraenkel J R and Wallen N E.: How to Design and Evaluate Research in Education Eight Edition. New York: McGraw Hill (2007) 